\title{
The study of characteristics through biomass burning
}

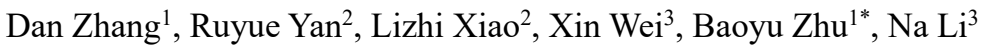 \\ 1. State Grid Jilin Electric Power Research Institute, Changchun, 130021, China \\ 2. Changchun University of Chinese Medicine, 130117, China \\ 3. Key Laboratory of Songliao Aquatic Environment, Ministry of Education, Jilin Jianzhu University, Changchun, 130118, China
}

\begin{abstract}
As a major agricultural province in China, Northeast China produces a lot of biomass while its grain yield is high. Open burning is an efficient and convenient way to remove biomass. However, air pollutants $\left(\mathrm{PM}_{2.5}, \mathrm{CO}\right.$, VOCs) will be released in the process of biomass combustion, which will have a certain impact on Regional Environmental quality, atmospheric visibility and human health. Because of the various type of biomass, their combustion products and effects are different. In this study, there collected peanut hull, rice husk, straw and wood particles, and carried out the simulated combustion experiment in the laboratory environment simulation chamber. The inorganic elements, water-soluble ions and speciation analysis of combustion products were determined. The results showed that the content of $\mathrm{Zn}$ was higher than that of carcinogenic element in the eight inorganic elements after combustion. The water-soluble ion emission factors of wheat straw and wood particles are larger than those of peanut hull and rice husk, and the water-soluble ions are mainly $\mathrm{K}^{+}$and $\mathrm{CL}^{-}$. Through the morphology analysis of combustion products, it can be seen that different types of biomass have different morphology after combustion, which are mainly strip, column and particle. Combined with energy spectrum analysis, it is found that the content of K and CL is high. The results lay a theoretical foundation for the study of local biomass combustion and provide data for the determination of local biomass combustion emission characteristics.
\end{abstract}

\section{Introduction}

Typical biomass combustion mainly includes four types: forest fire, open-air burning of agricultural straw, burning of wood and straw as agricultural fuel [1]. Biomass combustion will release air pollutants including $\mathrm{PM}_{2.5}, \mathrm{Co}$, VOCs and so on, which will have a certain degree of impact on regional environmental quality, atmospheric visibility, human health and climate change [2,3]. In recent years, different scholars have carried out research on biomass open-air combustion at different scales, including forest fires in Southeast Asia [4], North America [5] and Africa [6]. However, as a large agricultural country in the world, a large amount of straw is produced in the process of grain planting, and its open burning and indoor fuel consumption are the main forms of biomass combustion in China [7], and most of them are concentrated in Northeast China, North China Plain and Yangtze River Delta region [8]. In particular, Northeast China, as the main grain producing area in China, produces a large amount of biomass in the process of agricultural production. However, it is located in the northern cold area, and the plant growth period is relatively short. Open burning is the most efficient way to clean up the land [9]. According to research, about $20-30 \%$ of agricultural biomass is burned in the open air during the grain harvest season [10].
In previous studies, satellite remote sensing images and statistical data were mostly used to study the impact of biomass open-air combustion at different scales, such as regional, national and global [11]. However, there are few studies based on local biomass incineration. This limitation is mainly due to the variety of biomass and different combustion characteristics [12], so it is necessary to carry out combustion characteristics of different types of biomass in order to provide more accurate data support for the determination of local biomass combustion emissions and emission factors.

In this study, four biomass types including peanut hull, rice husk, straw and wood particles were selected. After testing and analyzing their basic physical and chemical properties, $\mathrm{PM}_{2.5}$ particles were collected and incinerated in the laboratory environment chamber. The inorganic elements and ionic components of $\mathrm{PM}_{2.5}$ particles were collected and incinerated. At the same time, scanning electron microscope (SEM) was used to analyze the combustion products and particulate matters of different biomass the results lay a theoretical foundation for the study of local biomass combustion characteristics, and provide data support for the determination of local biomass combustion emission characteristics. 


\section{Materials and methods}

\subsection{Biomass sample collection}

In this study, four types of biomass were selected: peanut hull, rice husk, straw and wood particles. They were collected in the rural areas around Changchun during the grain harvest season. In the process of collection, $1 \mathrm{~m} \times 1 \mathrm{~m}$ sampling points were selected and collected at the diagonal. During the collection process, the samples were cut and collected with ceramic scissors. Three samples were evenly collected and loaded to the sealed bag, record the sampling time, location and other data, and take it to the laboratory for determination of water content, volatile matter, calorific value and other physical and chemical properties (Table 1). The surplus samples are placed in $40{ }^{\circ} \mathrm{C}$ ultra-low temperature refrigerator for further experimental test.

\subsection{Determination of inorganic elements in biomass combustion samples and $\mathrm{PM}_{2.5}$ samples}

In daily life, biomass is often removed by outdoor field combustion, but the combustion conditions are not easy to control, and the flue gas is difficult to collect after diffusion, so this study adopts the method of Simulated Combustion in laboratory environment chamber. $5 \mathrm{~g}$ peanut husk, rice husk, wheat straw and wood particles were respectively weighed and placed on the tray covered with tin foil.

In the disk, the combustion simulation was carried out in the environment simulation bin with the size of $1 \mathrm{~m}^{3}$. Before the experiment, the exhaust air of the simulation bin was opened, and the exhaust valve was closed after exhaust for $3 \mathrm{~h}$. When the biomass began to burn, the flue gas $\mathrm{PM}_{2.5}$ was collected with the sampling flow rate of 30 $\mathrm{L} / \mathrm{min}$ and the sampling time of $30 \mathrm{~L} / \mathrm{min}$ Whatman quartz filter membrane was selected as the sampling membrane. The filter membrane was weighed before and after sampling and placed in the ultra-low temperature refrigerator for testing.

Take $1 / 4$ of the above $\mathrm{PM}_{2.5}$ filter membrane samples, cut them into small pieces with ceramic scissors, put them in the microwave digestion container, add $20 \mathrm{ml}$ nitric acid hydrochloric acid mixed digestion solution, immerse the filter membrane fragments in it, cover them, put them in the digestion tank assembly, screw them tightly, and put them on the microwave turntable frame. The digestion temperature was set at $200{ }^{\circ} \mathrm{C}$ and the digestion duration was $15 \mathrm{~min}$. after digestion, the digestion tank components were taken out and cooled. The inner wall of the microwave digestion container was washed with water, and about $10 \mathrm{ml}$ water was added, and the digestion was carried out for $0.5 \mathrm{~h}$. Filter the extract into a $50 \mathrm{ml}$ volumetric flask and fix the volume with water to $50 \mathrm{ml}$ scale. When the content of organic matter is too high,

Table1. Physicochemical properties of biomass and analysis of heavy metals after combustion appropriate amount of hydrogen peroxide can be added to decompose organic matter during digestion.

According to the standard of "determination of metal elements in air and exhaust gas particles by inductively coupled plasma atomic emission spectrometry" (HJ7772015), the contents of eight heavy metals including $\mathrm{Cu}, \mathrm{Pb}$, $\mathrm{Mn}, \mathrm{Cr}, \mathrm{CD}, \mathrm{Zn}$, as and $\mathrm{Ni}$ in biomass straw combustion and $\mathrm{PM}_{2.5}$ were quantitatively analyzed by ICP-OES.

\subsection{Ion composition analysis of biomass combustion samples}

Take $1 / 4$ of the above $\mathrm{PM}_{2.5}$ filter membrane sample, cut into small pieces with ceramic scissors and put into the sample bottle, add $100 \mathrm{ml} . \mathrm{Na}^{+}, \mathrm{K}^{+}, \mathrm{F}^{-}, \mathrm{Cl}^{-} \mathrm{NO}_{3}{ }^{-}$and $\mathrm{SO}_{4}{ }^{2-}$ were determined in this study.

\subsection{Morphology analysis of biomass combustion samples}

Field emission scanning electron microscopy (FESEM) combined with energy dispersive spectrometer (EDS) was used to analyze the microstructure and morphology of straw after combustion. Before the SEM/EDS test, the filter membrane was cut and dissected properly, and the basic tissue was observed under the electron microscope.

\section{Results and discussions}

\subsection{Emission characteristics of heavy metals after biomass combustion}

It can be seen from table 1 that the emission factors of $\mathrm{Cu}$, $\mathrm{Pb}, \mathrm{Mn}, \mathrm{Cr}, \mathrm{CD}, \mathrm{Zn}$ and $\mathrm{Ni}$ in $\mathrm{PM}_{2.5}$ from five kinds of biomass straw combustion flue gas are in the range of $2.15-901.99 \mu \mathrm{g} / \mathrm{kg}$. The emission factors of $\mathrm{Zn}$ particles are 525.58, 901.99, 397.76 and 592.72, in peanut hull, rice husk, wheat straw and wood, respectively. The emission factors of $\mathrm{Cr}, \mathrm{Pb}$ and $\mathrm{Cu}$ are higher, while $\mathrm{As}$ and $\mathrm{Mn}$ are lower.

It is also known from the table that the emission factors of the same heavy metals vary with different biomass types. The $\mathrm{Zn}$ emission factor of rice husk is higher than that of the other three biomasses and is relatively similar peanut hull and wood particles. Among the eight heavy metals, the emission factors of carcinogenic heavy metals $(\mathrm{Ni}, \mathrm{As}, \mathrm{CD}, \mathrm{Pb})$ are relatively low, among which the emission factors of As are the lowest. The emission factors of As in wheat straw and wood particles are $1 / 4$ and $1 / 20$ of peanut hull and rice husk, respectively. It shows that although the open burning of biomass will have different degrees of impact on the atmospheric environment quality, the emission of carcinogenic substances is relatively low.

\begin{tabular}{ccccc}
\hline & Peanut husk & Rice husk & Wheat straw & Wood particles \\
\hline Moisture $(\%)$ & 10.3 & 8 & 15.5 & 9 \\
Volatile $(\%)$ & 66.4 & 64 & 64.38 & 75.7
\end{tabular}




$\begin{array}{ccccc}\text { Calorific value }(\mathrm{kcal} / \mathrm{kg}) & 3453.822 & 3762.19 & 2867.92 & 3855.89 \\ \mathrm{Cr}(\mu \mathrm{g} / \mathrm{kg}) & 33.24 & 15.16 & 21.09 & 37.20 \\ \mathrm{Mn}(\mu \mathrm{g} / \mathrm{kg}) & 22.25 & 13.33 & 14.37 & 21.80 \\ \mathrm{Ni}(\mu \mathrm{g} / \mathrm{kg}) & 8.01 & 13.70 & 13.83 & 10.83 \\ \mathrm{Cu}(\mu \mathrm{g} / \mathrm{kg}) & 25.71 & 21.68 & 38.60 & 9.11 \\ \mathrm{Zn}(\mu \mathrm{g} / \mathrm{kg}) & 525.58 & 901.99 & 397.76 & 592.72 \\ \mathrm{As}(\mu \mathrm{g} / \mathrm{kg}) & 9.11 & 42.43 & 2.15 & 2.94 \\ \mathrm{Cd}(\mu \mathrm{g} / \mathrm{kg}) & 13.80 & 17.50 & 21.41 & 17.56 \\ \mathrm{~Pb}(\mu \mathrm{g} / \mathrm{kg}) & 22.70 & 16.79 & 25.04 & 33.06\end{array}$

\subsection{Analysis of ion composition after biomass combustion}

The water-soluble ion components of peanut hull, rice husk, wheat straw and wood particles are mainly shown in Table 2. The water-soluble ion emission factors of different biomass are in the range of 10.29-168.17 mg/kg. $\mathrm{K}^{+}$and $\mathrm{Cl}^{-}$are the two inorganic water-soluble ions with the largest emission factors of biomass combustion. The emission factor of $\mathrm{SO}_{4}{ }^{2-}$ is next to $\mathrm{K}^{+}$and $\mathrm{Cl}^{-}$and the lowest is $\mathrm{NO}_{3}^{-}$. The results showed that the $\mathrm{K}^{+}$emission factor of wheat straw $(131.75 \mathrm{mg} / \mathrm{kg})$ was the largest, which was 1.65 times of peanut straw $(79.73 \mathrm{mg} / \mathrm{kg})$, and the $\mathrm{Cl}^{-}$emission factor of wood particles $(168.17 \mathrm{mg} / \mathrm{kg})$ was 1.47 times of rice husk $(114.37 \mathrm{mg} / \mathrm{kg})$, indicating that the four biomass emitted more $\mathrm{K}^{+}$and $\mathrm{Cl}^{-}$, which accounted for $65.85 \%-74.69 \%$ in the total water-soluble ions. The results showed that the content of $\mathrm{K}^{+}$and $\mathrm{Cl}^{-}$ from straw combustion was the highest in water-soluble ions, and previous studies [13] showed that the concentration of $\mathrm{K}^{+}$and $\mathrm{Cl}^{-}$in urban atmosphere increased significantly during straw burning, which was consistent with the results of this study.

On the whole, the water-soluble ions emitted by wheat straw and wood particles were $390.85 \mathrm{mg} / \mathrm{kg}$ and $392.9 \mathrm{mg} / \mathrm{kg}$, respectively, which were higher than those of peanut hull and rice husk $(300.75 \mathrm{mg} / \mathrm{kg}, 310.88$ $\mathrm{mg} / \mathrm{kg}$ ), respectively. Therefore, compared with the other two biomasses, the combustion of peanut hull and rice husk contributed more. The emission factors of $\mathrm{F}^{-}, \mathrm{NO}_{3}{ }^{-}$, $\mathrm{SO}_{4}{ }^{2-}$ and $\mathrm{Na}^{+}$are relatively low in six water-soluble ions. Relevant studies show that they mainly come from fluoride plants, vehicle exhaust, smelting plants, sea salt and so on $[14,15]$. While $\mathrm{K}^{+}$mainly comes from biomass combustion [16], and $\mathrm{Cl}^{-}$is related to coal combustion and biomass combustion $[17,18]$. Therefore, it can be seen that biomass combustion has an inapparent impact on $\mathrm{F}^{-}, \mathrm{NO}_{3}{ }^{-}$, $\mathrm{SO}_{4}{ }^{2-}$ and $\mathrm{Na}^{+}$, and has an obvious impact on $\mathrm{K}^{+}$and $\mathrm{Cl}^{-}$.

Table2. Analysis of ion composition after biomass combustion

\begin{tabular}{ccccc}
\hline & Peanut husk & Rice husk & Wheat straw & Wood particles \\
\hline $\mathrm{K}^{+}(\mathrm{mg} / \mathrm{kg})$ & 79.73 & 99.39 & 131.75 & 114.35 \\
$\mathrm{Na}^{+}(\mathrm{mg} / \mathrm{kg})$ & 24.95 & 27.74 & 31.14 & 25.25 \\
$\mathrm{~F}^{-}(\mathrm{mg} / \mathrm{kg})$ & 17.19 & 14.59 & 22.50 & 18.37 \\
$\mathrm{Cl}^{-}(\mathrm{mg} / \mathrm{kg})$ & 118.31 & 114.37 & 160.17 & 168.17 \\
$\mathrm{NO}_{3}^{-}(\mathrm{mg} / \mathrm{kg})$ & 10.46 & 10.29 & 10.82 & 17.14 \\
$\mathrm{SO}_{4}^{2-}(\mathrm{mg} / \mathrm{kg})$ & 50.11 & 44.50 & 34.47 & 49.62 \\
\hline
\end{tabular}

\subsection{Morphology analysis of biomass after combustion}

The following figure shows the SEM pictures of the basic organization of the combustion products of different biomass. It can be seen that the morphology of the four types of biomass is different after combustion. The morphology of wheat straw and rice husk is mainly long strip, while the morphology of peanut shell is mainly columnar particles. The morphology of wood particles can be seen in both strip and column shape, and spherical particles of different sizes are attached on the surface. The results show that there are obvious protuberant particles on the surface, showing a high content of inorganic salts. Analysis shows that the content of $\mathrm{K}$ and $\mathrm{Cl}$ is high.

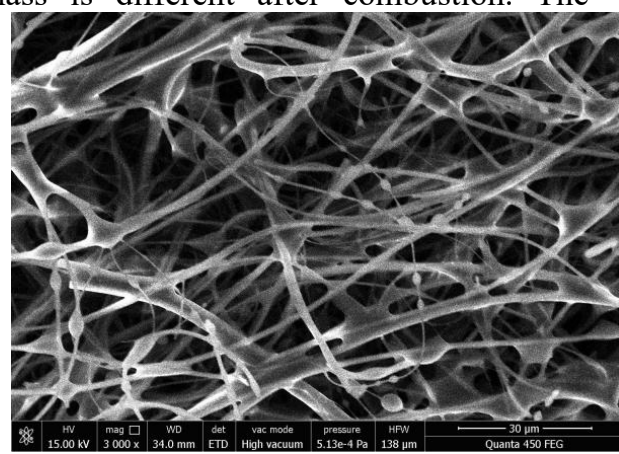

(a). Wheat straw

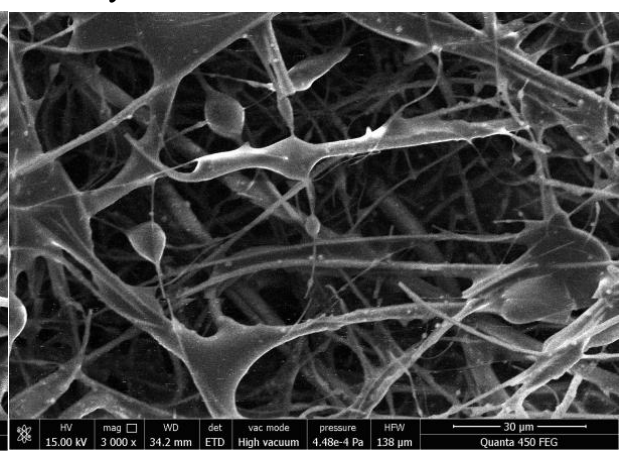

(b). rice husk 


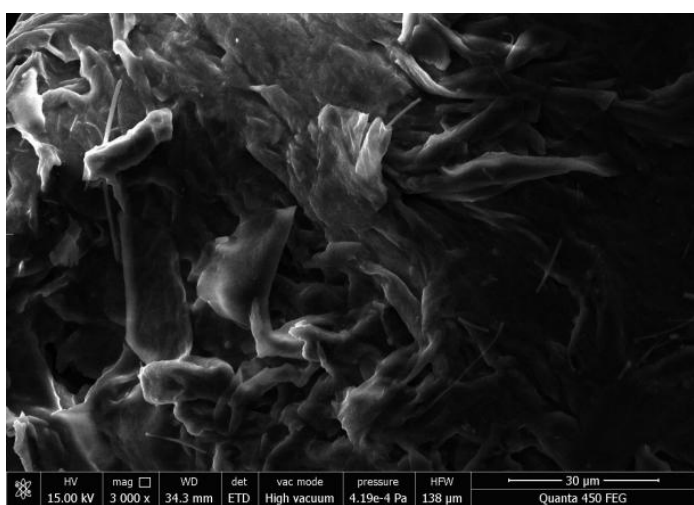

(c). Peanut shell

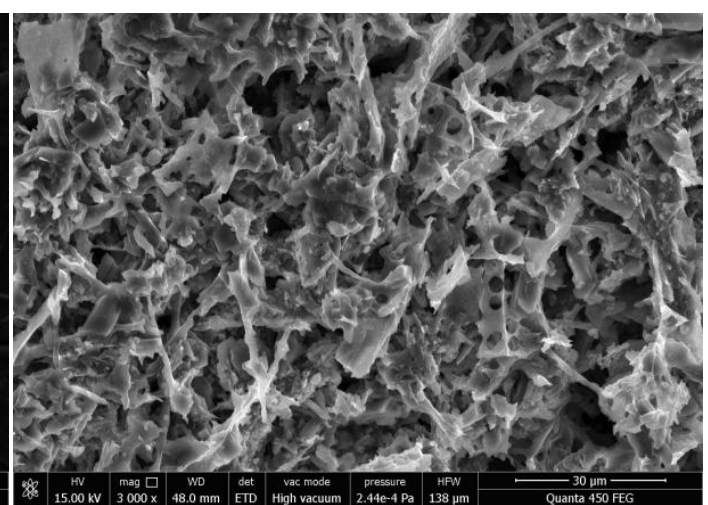

(d). wood particles

\section{Conclusions}

In this study, four different types of biomass including peanut hull, rice husk, wheat straw and wood particles were selected. The simulated combustion experiment was carried out in an indoor closed environment chamber. The inorganic elements, ion composition and morphology of smoke and dust after different types of biomass combustion were determined. The conclusion is as follows:

(1) The results showed that the content of $\mathrm{Zn}$ was higher than that of carcinogenic element in the eight inorganic elements.

(2) The results show that the content of CL in anions is higher than that in cations.

(3) Scanning electron microscopy (SEM) was used to observe the morphology of combustion products of four kinds of biomass. It can be seen that there are different shapes such as strip and column. Combined with energy spectrum analysis, the contents of $\mathrm{K}$ and $\mathrm{Cl}$ in the products are relatively high.

\section{Acknowledgments}

This work was financially supported by Electric Power Research Institute of State Grid Jilin Electric Power Co., Ltd. (preparation and modification of iron-based low temperature SCR denitration catalyst for thermal power plant)

\section{References}

1. Chen, J., Li, C., Ristovski, Z., Milic, A., Gu, Y., Islam, M.S., et al., 2017. A review of biomass burning: emissions and impacts on air quality, health and climate in China. Sci. Total Environ. 579, 1000-1034.

2. Wu, Y., Han, Y., Voulgarakis, A., Wang, T., Li, M., Wang, Y., et al., 2017. An agricultural biomass burning episode in eastern China: Transport, optical properties, and impacts on regional air quality. Journal of Geophysical Research: Atmospheres 122, 2304-2324.

3. Taylor, D., 2009. Biomass burning, humans and climate change in Southeast Asia. Biodivers. Conserv. 19, 1025-1042.
4. Guo Wenkai, Liu Zhen, Liu Wenbo, et al. Emission characteristics of VOCs from biomass combustion and its impact on atmospheric environment in Lanzhou, China Environmental Science, 2019,39 (1): $40 \sim 49$.

5. Munoz-Alpizar, R., Pavlovic, R., Moran, M., Chen, J., Gravel, S., Henderson, S., et al., 2017. Multi-year (2013-2016) PM2.5 wildfire pollution exposure over North America as determined from operational air quality forecasts. Atmosphere 8, 179.

6. Vakkari, V., Beukes, J.P., Dal Maso, M., Aurela, M., Josipovic, M., van Zyl, P.G., 2018. Major secondary aerosol formation in southern African open biomass burning plumes. Nat. Geosci. 11, 580-583.

7. Zhao, H., Zhang, X., Zhang, S., Chen, W., Tong, D., Xiu, A., 2017. Effects of agricultural biomass burning on regional haze in China: a review. Atmosphere 8.

8. Long, X., Tie, X., Cao, J., Huang, R., Feng, T., Li, N., et al., 2016. Impact of crop field burning and mountains on heavy haze in the North China Plain: a case study. Atmos. Chem. Phys. 16, 9675-9691.

9. Wang, J., Zhao, B., Wang, S., Yang, F., Xing, J., Morawska, L., et al., 2017. Particulate matter pollution over China and the effects of control policies. Sci. Total Environ. 584, 426-447.

10. Chen, J., Gong, Y., Wang, S., Guan, B., Balkovic, J., Kraxner, F., 2019a. To burn or retain crop residues on croplands? An integrated analysis of crop residue management in China. Sci. Total Environ. 662, 141150.

11. Li, F., Zhang, X., Roy, D.P., Kondragunta, S., 2019. Estimation of biomass-burning emissions by fusing the fire radiative power retrievals from polar-orbiting and geostationary satellites across the conterminous United States. Atmos. Environ. 211, 274-287.

12. Zhang, H., Hu, D., Chen, J., Ye, X., Wang, S.X., Hao, J.M., et al., 2011. Particle size distribution and polycyclic aromatic hydrocarbons emissions from agricultural crop residue burning. Environ. Sci. Technol. 45, 5477-5482.

13. Zhang Y.S., Shao M., Lin Y., et al. Emission inventory of carbonaceous pollutants from biomass burning in the Pearl River Delta Region, China [J]. Atmospheric Environment, 2013, 76 (5): 189-199. 
14. Cheng Yuan, Wu Jianhui, Bi Xiaohui, et al. Pollution characteristics and sources of water-soluble ions in PM2.5 in Wuhan, Chinese Journal of Environmental Sciences, 2019, 39 (1): 189-196.

15. Tang Xibin. Impact analysis of straw burning on haze and emission factors and particulate matter composition spectrum [D]. East China University of science and technology, 2014.

16. Liu Haili, Peng Lin, Zhang Teng, et al. Distribution characteristics of carbon components and watersoluble inorganic ions in agricultural and forestry biomass combustion dust [J], Journal of environmental engineering, 2017, 11 (3): 1672-1676.

17. Ju Yuanhua, Yang xiajie, Jin Quanfeng, et al. Analysis of PM2.5 emission factors and main components of crop straw under different combustion states [J], Journal of environmental science, 2018, 38 (1): 92100.

18. Zhang Zongwei, Hu Gongren, Yu Ruilian, et al. Pollution characteristics and source apportionment of water-soluble ions in atmospheric PM2.5 in Xiamen [J], Chinese Journal of Environmental Sciences, 2016, 36 (7): 1947-1954. 